\title{
HUMAN BUCCAL EPITHELIUM CELL RESPONSE TO LOW INTENSIVE NEUTRON RADIATION
}

\author{
K.A. Kuznetsov' ${ }^{1}$, P.S. Kyzym², A.Yu. Berezhnoy ${ }^{2}$, A.F. Shchus ${ }^{2}$, \\ G.M. Onishchenko ${ }^{2}$, Yu.G. Shckorbatov ${ }^{2}$ \\ ${ }^{I}$ Kharkiv National Medical University, 4 Nauky Av., Kharkiv, 61022, Ukraine \\ ${ }^{2}$ V.N. Karazin Kharkiv National University, 4 Svobody Sq., Kharkiv, 61022, Ukraine \\ e-mail:Konst.Kuznets@gmail.com \\ Submitted November 13, 2017 \\ Accepted July 24, 2018
}

Background: The investigation of the low doses of ionizing radiation is still a great importance for identification of the threshold of harmful effect and potential hormetic effect of low doses.

Objectives: The purpose of investigation was to evaluate the stress response in human buccal epithelium cells induced by low intensive neutron radiation.

Materials and Methods: The level of chromatin condensation in interphase nuclei was applied for assessment of the cell reaction to stress. Exfoliated human buccal epithelium cells were collected, placed in the $3.03 \mathrm{mM}$ phosphate buffer solution $(\mathrm{pH}=7.0)$ with addition of $2.89 \mathrm{mM} \mathrm{CaCl}_{2}$ and exposed to neutron radiation from $2 \mathrm{Pu}-\mathrm{Be}$ sources IBN-17. The heterochromatin granule quantity (HGQ) assessments were done after orcein staining that had been immediately performed after cell exposure to neutron radiation in the dose range from $2.3 \mathrm{mSv}$ to $146.0 \mathrm{mSv}$. Also the effect of fast neutron radiation in the dose of $11.4 \mathrm{mSv}$ on human buccal epithelium cells was investigated in 1-64 min after exposure. The HGQ in every variant of experiment was assessed in 30 nuclei in 3 separate experiments. The mean HGQ and standard error of mean were assessed in every experiment.

Results: Neutron radiation induced the increase of HGQ. Partially slowed neutrons have less influence on neutron-induced HGQ increase than only fast neutrons especially with 1 min delay after exposure. Fast neutrons induce heterochromatinization in cell samples irradiated with doses $4.6-36.5 \mathrm{mSv}$. Further increase of dose has led to return of HGQ to control levels. After cell exposure to fast neutron flow $(11.4 \mathrm{mSv})$ the peaks of chromatin condensation were observed for time intervals 2-8 and 32-64 min after cell exposure to radiation.

Conclusions: Qualitative characteristic of neutron radiation (slow/fast neutrons) influences the rate of cell stress response as revealed by chromatin condensation in cell nuclei. It was demonstrated that there is a threshold dose above which cells are able to develop stress response to neutron radiation. The doseresponse dependence is non-monotonous and is of wave-like form. Described phenomena may be explained by the effect of hormesis.

KEY WORDS: buccal epithelium; neutron radiation; cell stress; chromatin.

\section{РЕАКЦІЯ КЛІТИН БУКАЛЬНОГО ЕПІТЕЛІЮ ЛЮДИНИ НА НИЗЬКОІНТЕНСИВНЕ НЕЙТРОННЕ ОПРОМІНЮВАННЯ}

К.А. Кузнецов ${ }^{1}$, П.С. Кизим ${ }^{2}$, А.Ю. Бережной ${ }^{2}$ О.П. Щусь ${ }^{2}$, Г.М. Оніщенко

${ }^{1}$ Харківський національний медичний університет, пр-т Науки, 4, Харків, 61022, Украӥна

${ }^{2}$ Харківський національний університет імені В.Н. Каразіна, пл. Свободи, 4, Харків, 61022, Україна

Актуальність. Дослідження малих доз іонізуючого випромінювання все ще має велике значення у зв'язку з визначенням межі діапазону доз, що мають шкідливий ефект та у зв'язку з дослідженням можливого горметичного ефекту малих доз радіації.

Мета роботи. Метою дослідження було оцінити стресову реакцію в клітинах букального епітелію людини, під впливом низькоінтенсивного нейтронного випромінювання.

Матеріали та методи. В якості показника стресової реакції клітини застосовувався рівень конденсації хроматину в інтерфазних ядрах. Клітини букального епітелію людини були взяті у донора, поміщені в 3,0 мМ фосфатний буферний розчин ( $\mathrm{pH}=7,0)$ з додаванням 2,89 $\mathrm{MM} \mathrm{CaCl}_{2} \mathrm{i}$ піддані впливу нейтронного випромінювання з 2 джерел $\mathrm{Pu}-\mathrm{Be}$ ИБН-17. Оцінку вмісту гранул гетерохроматину (ВГГ) проводили відразу після опромінення клітин дозами 2,3-146,0 мЗв. Ефект

(C) Kuznetsov K.A., Kyzym P.S., Berezhnoy A.Yu., Shchus A.F., Onishchenko G.M., Shckorbatov Y.G., 2018 

Y.G. Shckorbatov

дози 11,4 мЗв досліджували через 1-64 хв. після експозиції. Ступінь конденсації хроматину в кожному варіанті експерименту оцінювався у 30 ядрах у 3-х повторностях за середнім значенням ВГГ після забарвлення орсеїном з визначенням стандартної похибки середнього значення.

Результати. Низькоінтенсивне нейтронне випромінювання викликало підвищення ВГГ. Потік частково сповільнених нейтронів мав менший вплив на зростання ВГГ, ніж швидкі нейтрони, особливо після опромінення протягом 1 хв. Нейтронне випромінювання посилювало гетерохроматинізацію в діапазоні доз 4,6-36,5 мЗв. Подальше збільшення дози призвело до повернення ВГГ до контрольного рівня. При опроміненні нейтронами у дозі 11,4 м3в піки конденсації хроматину спостерігались в періоди 2-8 та 32 хв. після завершення опромінення.

Висновки. Якісні характеристики нейтронного випромінювання (наявність сповільнених/швидких нейтронів) впливають на розвиток стресової реакції клітини, яка проявлялася в підвищенні кількості гранул гетерохроматину в ядрі. Показано існування порогу здатності клітин до гетерохроматинізацї у відповідь на нейтронне випромінювання. Залежність доза-ефект немонотонна та має хвилеподібну форму. На нашу думку, даний факт можна пояснити ефектом гормезису.

КЛЮЧОВІ СЛОВА: букальний епітелій; нейтронне випромінювання; клітинний стрес; хроматин.

\section{РЕАКЦИЯ КЛЕТОК БУККАЛЬНОГО ЭПИТЕЛИЯ ЧЕЛОВЕКА НА НИЗКОИНТЕНСИВНОЕ НЕЙТРОННОЕ ОБЛУЧЕНИЕ}

К.А. Кузнецов ${ }^{1}$, П.С. Кизим ${ }^{2}$, А.Ю. Бережной ${ }^{2}$, А.Ф. Щусь ${ }^{2}$, Г.М. Онищенко ${ }^{2}$ Ю.Г. Шкорбатов ${ }^{2}$

${ }^{l}$ Харьковский наичональный медицинский университет, пр-т Науки, 4, Харьков, 61022, Украина

${ }^{2}$ Харьковский национальный университет имени В.Н. Каразина, пл. Свободы, 4, Харьков, 61022, Украина

Актуальность. Исследования малых доз ионизирующего излучения все еще имеет большое значение в связи с определением нижней границы диапазона доз, которые имеют повреждающий эффект и в связи с исследованием возможного эффекта гормезиса при действии малых доз радиации.

Цель работы. Целью исследования являлась оценка степени стрессовой реакции клеток буккального эпителия человека на воздействие низкоинтенсивного нейтронного излучения.

Материалы и методы. В качестве показателя стрессовой реакции использовалось содержание гранул гетерохроматина (СГГ) в интерфазных ядрах. Взятые у донора клетки буккального эпителия человека помещали в 3,03 мМ фосфатный буферный раствор $(\mathrm{pH}=7,0)$ с добавлением $2,89 \mathrm{MM} \mathrm{CaCl}_{2}$ и обрабатывали нейтронным излучением из двух источников $\mathrm{Pu}-\mathrm{Be}$ ИБН-17 в диапазоне доз 2,3-146,0 мЗв. В данном случае эффект облучении исследовали непосредственно после облучения. Эффект дозы 11,4 мЗв исследовался спустя 1-64 мин после окончания облучения. Степень конденсации хроматина в каждом варианте эксперимента оценивали в 30 ядрах в трех повторностях по среднему значению гранул гетерохроматина в ядрах клеток после окрашивания орсеином с учётом стандартной ошибки среднего.

Результаты. Низкоинтенсивное нейтронное излучение вызвало повышение СГГ. Частично замедленные нейтроны оказывали меньшее влияние на радиационно-индуцированное увеличение СГГ, чем быстрые нейтроны, особенно спустя 1 мин. после окончания облучения. Нейтронное излучение вызвало повышение уровня гетерохроматинизации при дозах 4,6-36,5 мЗв. Дальнейшее увеличение дозы привело к возврату СГГ к контрольным значениям. При воздействии 11,4 м3в быстрых нейтронов пики конденсации хроматина наблюдались после 2-8 и 32 мин по окончании обучения.

Выводы. Качественные характеристики нейтронного излучения (наличие медленных/быстрых нейтронов в потоке) влияет на характер развития реакции клеточного стресса, которая проявлялась в повышении количества гранул гетерохроматина в ядре. Предполагается, что существует порог в способности клеток к реагированию на нейтронное излучение, зависимость доза-эффект немонотонна и имеет волнообразную форму.

КЛЮЧЕВЫЕ СЛОВА: буккальный эпителий; нейтронное излучение; клеточный стресс; хроматин.

Biological effects of corpuscular ionizing radiation are generally more expressive than those produced by $\mathrm{X}$-ray and $\gamma$-radiation $[1,2,3]$. It is assumed that the biological efficiency of neutron radiation is about $2-20$ times, depending on the energy of particles, higher than of $\gamma$-radiation [1].

High doses of neutron radiation induce chromosome damage [4], affect p53-expression [2]. The low-dose neutron irradiation causes both hormetic [5] and damaging [6,7] effects. 
Human buccal epithelium cell response to low intensive neutron radiation

Exposure to fast neutrons $(17 \mathrm{MeV})$ has higher biological efficiency than gamma-radiation, the neutrons had a relative biological effectiveness of 2.1 for micronuclei and 5.8 for bridges in cells of normal human lymphoblastoid cell lines (GM15036 and GM15510) compared to gamma-radiation produced by ${ }^{60} \mathrm{Co}$ [8]. The level of expression of the gene PIG3 (mRNA and protein level) increases in a dose dependent manner in AHH-1 cells exposed to $\gamma$-rays and neutrons. The level of PIG3 expression is suggested as a potential radiation exposure biomarker [9]. There is the evidence [10] of the role of a signaling pathway NF- $\kappa B$ in the elimination of the consequences of exposure to neutron radiation. The neutron radiation is used in medicine, for medical treatment of cancer patients. For example, the effectiveness of therapy of patients with malignant brain tumors is demonstrated [11].

Previously, to determine the biological effect of ionizing radiation the indicator of cell stress response - condensation of chromatin was used (the nonspecific response to external hazard) [12]. The chromatin in interphase cell nucleus is presented in two forms: euchromatin (decondensed, transcriptionally active) and heterochromatin (condensed, transcriptionally inactive). Therefore, by measuring the portion of heterochromatin in interphase cell nucleus one can assess the level of functional activity of cell nucleus. Changes of the degree of chromatin condensation in buccal epithelium cells may be used for assessment of cell reaction to external stress factors [13].

Thus, the problem of medical application of neutron exposure for treating tumors is accompanied by the exposure to low intensity irradiation of adjacent tissues. The cell state and the measurable characters of the cell state in these tissues are very important. The aim of our research was to investigate the effect of low intensity neutron radiation on the state of chromatin in human cells.

\section{MATERIALS AND METHODS}

A primary cell culture of human buccal epithelium cells was used in our experiments as an experimental model. The primary cell cultures are used in many in vitro investigations, review of application of primary cell cultures in biotechnology is done in [14]. There are many works applying the primary cell cultures for research purposes, for instance, the primary cells of adult human epidermal keratinocytes (HEKa) obtained from one single donor [15]. Many investigations are conducted on primary human skin fibroblasts (HSF) obtained from one single donor [16]. Therefore, our investigation conducted on primary cell culture of cells of one single donor is in a row with many others investigations of this type.

Buccal epithelium cells in this investigation were obtained from 24 year old donor (man). Cells were scraped from cheek mucosa with a sterile blunt spatula. Cells were placed in the $3.03 \mathrm{mM}$ phosphate buffer solution with addition of $2.89 \mathrm{mM} \mathrm{CaCl}_{2}(\mathrm{pH}=7.0)[12,17]$.

The sources of neutron radiation were two Pu-Be sources IBN-17 (energy range $100 \mathrm{keV}$ $-10 \mathrm{MeV}$ with a quantity peak at $4.5 \mathrm{MeV}, 5 \times 10^{7} \mathrm{n} / \mathrm{sec}$., isotropic distribution). Slowing up to $10 \%$ of neutrons of was obtained by using $3.5 \mathrm{~cm}$ paraffin barrier. In experiments with fast neutrons the existing thermal neutrons were blocked by using $2 \mathrm{~mm} \mathrm{Cd}$ barrier. The gammaradiation $(59 \mathrm{keV})$ emitted by the neutron source was blocked by $2 \mathrm{~mm}$ layer of $\mathrm{Pb}$. After orcein staining the heterochromatin granules quantity (HGQ) was assessed in each of 30 nuclei randomly taken into analysis. Three independent experiments (repeats of experiment) were done in every variant of experiment. In total $90=30 \times 3$ cells were analyzed in each variant of experiment. Cells were analyzed in photographs made at magnification 400x. MICMED-7 microscope and Eyepiece Digital Microscope Camera HDCE-30C were used to obtain microphotographs for analysis.

The time of cell exposure in different experiments varied from 1 to $64 \mathrm{~min}$. The doses received by the cells are presented in Tab. 1. This range of doses has been chosen to 

Y.G. Shckorbatov

determine possible cell response to low and very low doses (a low dose is $<100 \mathrm{mGy}$ delivered acutely [18]), while in the most of articles published before and analyzed in this paper were used the doses from low $[5,6,19]$ to medium $[8,10,19,20]$ and high [11].

All experiments were done at a room temperature $\left(23^{\circ} \mathrm{C}\right)$. Cells were stained for $30 \mathrm{~min}$ by $2 \%$ orcein solution in $45 \%$ acetic acid. In this condition cells were killed and fixated immediately after addition of the staining solution. In the first experiment the cells were exposed to neutron radiation during $5 \mathrm{~min}$ ( $11.4 \mathrm{mSv}$ dose received), the time between the end of cell exposure to neutrons and cell staining (delay time) varied from 1 to $64 \mathrm{~min}$ (Fig. 1, 2). In the second and third experiments cells were stained 4 min after cell exposure (Fig. 3 and 4).

Tab.1. Doses of neutron radiation received according to the overall exposure period (calculated from neutron fluence using an approach described earlier [21] and includes type-of-radiation factor which is 10 for neutrons of energy range used in our investigation [1]).

\begin{tabular}{|l|c|c|}
\hline No & Exposure time, min. & Equivalent dose, $\mathrm{mSv}$ \\
\hline 1. & 1 & 2.3 \\
\hline 2. & 2 & 4.6 \\
\hline 3. & 4 & 9.1 \\
\hline 4. & 5 & 11.4 \\
\hline 5. & 8 & 18.3 \\
\hline 6. & 12 & 27.4 \\
\hline 7. & 16 & 36.5 \\
\hline 8. & 20 & 45.7 \\
\hline 9. & 24 & 54.8 \\
\hline 10. & 28 & 63.9 \\
\hline 11. & 32 & 73.1 \\
\hline 12. & 64 & 146.0 \\
\hline
\end{tabular}

The assessment of HGQ in control samples were done at the end of experiment (sham control). The mean HGQ for cell sample and standard error of the mean were calculated, the results were processed by Student's method with Bonferroni's multiple comparisons correction. In all the figures the mean values and SEM are presented. The level of probability assumed in this paper is $\mathrm{p}<0.05$.

\section{RESULTS AND DISCUSSION}

In a part of experiments two control samples were analyzed - at the beginning and after the experiment. The value of HGQ in two controls not changed significantly (Fig. 1).

According to obtained data, heterochromatin granules quantity under exposure to $11.4 \mathrm{mSv}$ neutron radiation depends on the part of slowed neutron in the flux. Exposure to pure fast neutrons has resulted in a stronger cell response $10 \mathrm{~min}$ after cell exposure (here). At $1 \mathrm{~min}$ after the exposure there was a peak of HGQ values. In case of partially slowed neutrons the increase in granules quantity was $12 \%$ above control levels and in case of only fast neutron $-17 \%$.

Neutron flux without slowed neutron fraction induced the more significant changes in HGQ (Fig. 2b). Henceforth the assessment of buccal epithelium cell stress reaction to the mentioned dose of fast neutron radiation was performed within the period 1-64 min. The results are presented in Fig.2. The data has shown that the first peak of HGQ value increase was observed at $4 \mathrm{~min}$ after cell exposure and the second HGQ peak was detected at $32 \mathrm{~min}$ 
after cell exposure. In comparison with previous experiment the radiation-induced heterochromatinization develops a bit later.

The dependence of chromatin condensation in the nuclei depended non-linearly from exposure time in wave-like progression. Such changes manifest the continuous cell response which is probably connected with reparation of chromatin due to chemical stage of radiation damage. In the next series of experiments cell has been stained at different periods of time after exposure to fast neutrons to investigate dynamics of development of cell heterochromatinization process induced by fast neutron irradiation (Fig. 2).

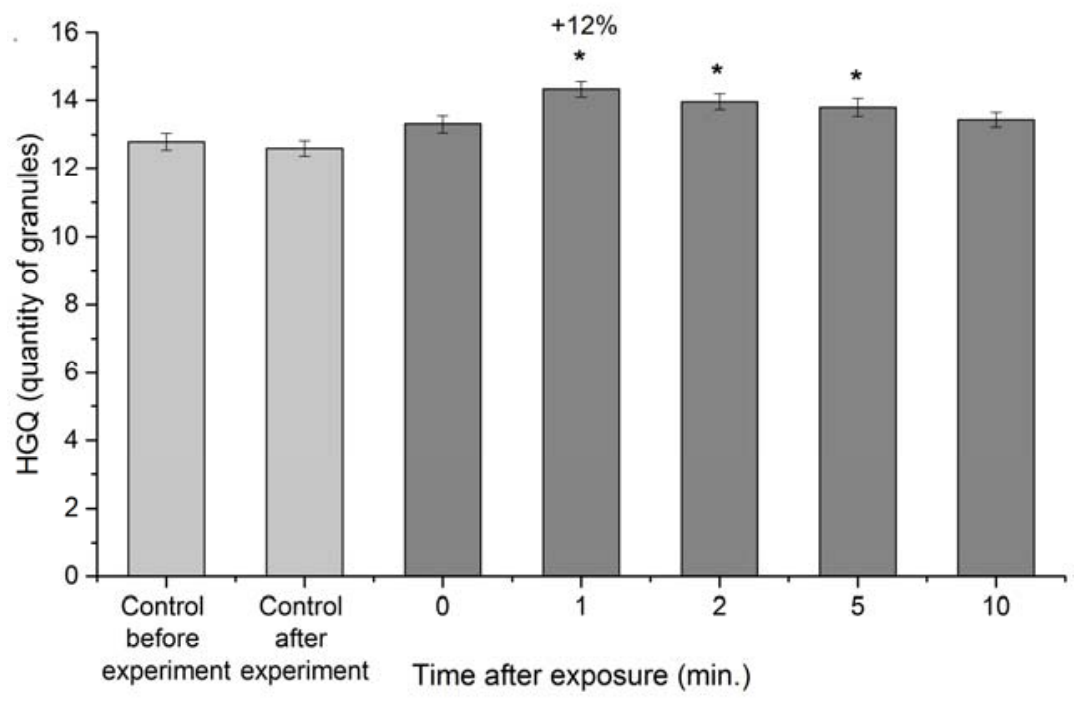

a)

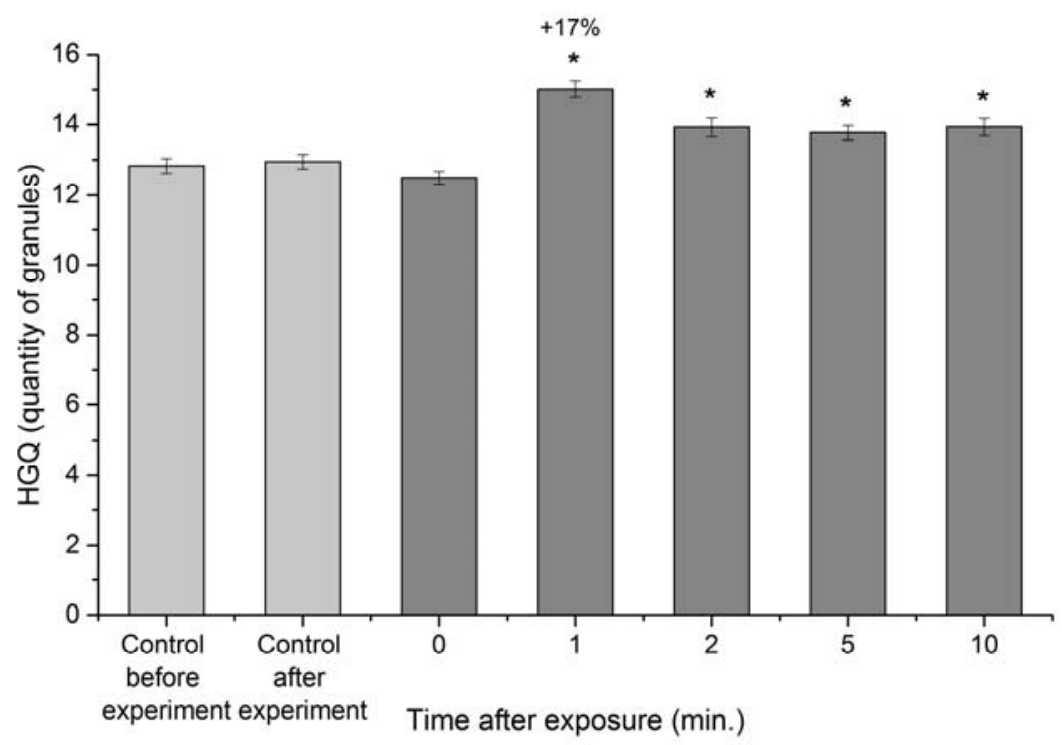

b)

Fig. 1. Changes in chromatin condensation of human buccal epithelium cells exposed to partially slowed neutron flux (a) and fast neutron radiation (b), the exposure time was 5 min and the dose was $11.4 \mathrm{mSv}$. Numbers above bars indicate the increase of HGQ in comparison to control. $*$ - significant difference $(\mathrm{p}<0.05)$ from control.

The significant HGQ increase was induced by exposure to $4.6-36.5 \mathrm{mSv}$ doses of neutron radiation. The exposure to 73.1 and $146 \mathrm{mSv}$ not induced HGQ increase (Fig. 3). Thus, the effect of chromatin condensation in nuclei does not show a proportional doseresponse effect. 

Y.G. Shckorbatov

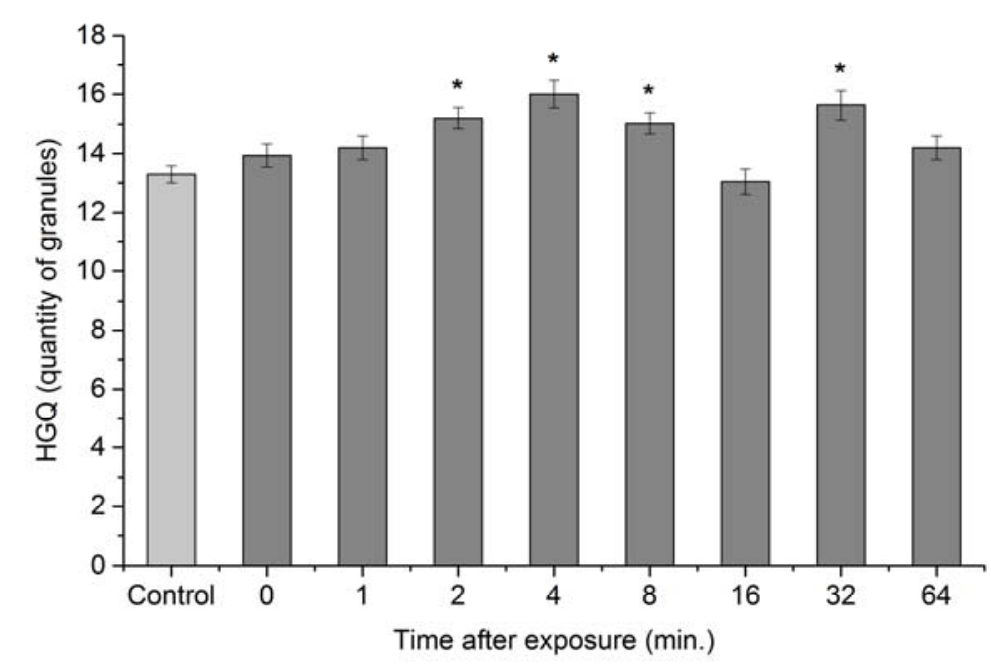

Fig. 2. HGQ in human buccal epithelium cells to $11.4 \mathrm{mSv}$ fast neutron radiation in different periods after irradiation.

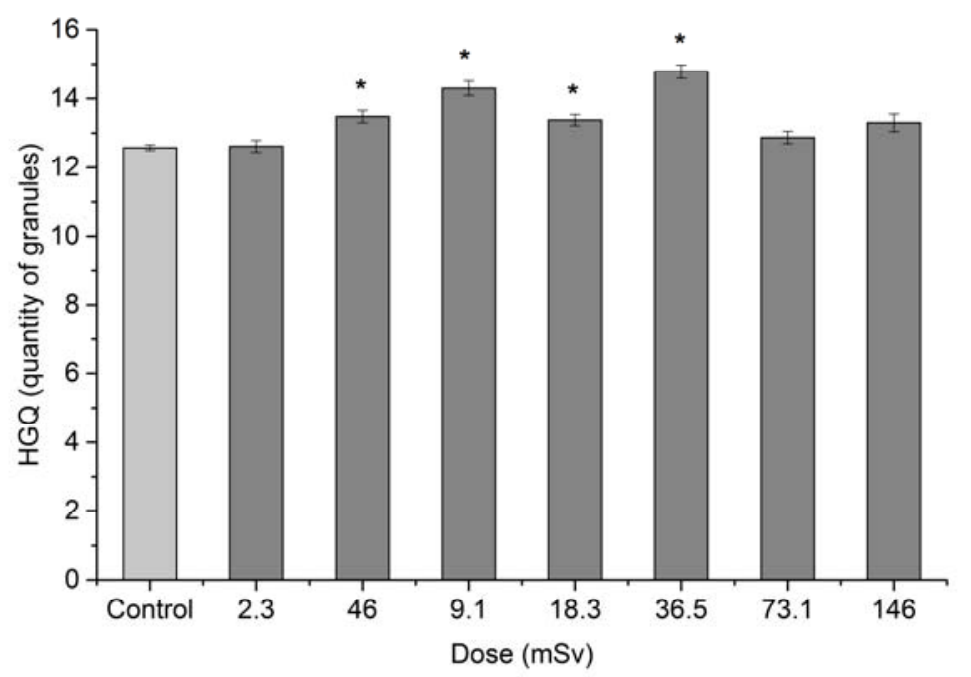

Fig. 3. Heterochromatinization in human buccal epithelium cells exposed to different doses of fast neutron radiation (stained at 4 th min after irradiation).

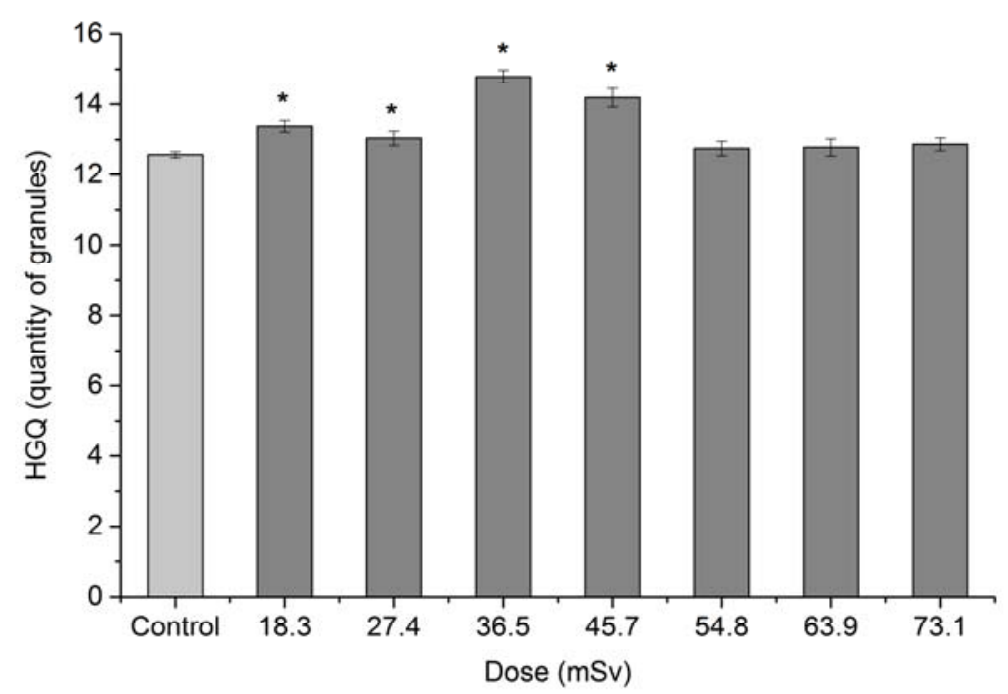

Fig. 4. Heterochromatinization in human buccal epithelium cells exposed to different doses of fast neutron radiation ( $9.1 \mathrm{mSv}$ interval between doses; stained at 4 th min after irradiation). 
Human buccal epithelium cell response to low intensive neutron radiation

To define more accurately the doses of neutron radiation inducing maximal HGQ increase and its further decrease, we investigated the effect of different doses of neutron radiation exposure with $9.1 \mathrm{mSv}$ ( 4 min of irradiation which is also the period of first HGQpeak formation under exposure to neutron radiation, Fig. 3) interval between doses (Fig. 4).

Based on the data of Fig. 4 it can be considered that the maximum changes in chromatin condensation are observed in cells exposed to fast neutron radiation $36.6 \mathrm{mSv}$. However, the HGQ index returns to the control level if cells are exposed to neutron radiation 54.8 $73.1 \mathrm{mSv}$. Thus, the disproportionate dose-effect relationship demonstrated in the previous experiment (Fig. 3) is confirmed. We suppose that the observed wavy effect of HGQ increase and HGQ reverse to the control level at above $45.7 \mathrm{mSv}$ exposure may be explained by temporal loss of cell ability to answer to stress by heterochromatinization (normally appearing at the stress cell reaction and detected at lower levels of exposure) or by hormesis effect. The non-monotonic dose-response effects, especially at ultra-low doses, are known in radiobiology for many years. For instance, such effect was revealed in the work [22], analyzing effects of X-rays on yeast. Let us quote from this work: "Hence we can state that: i) one should not take for granted a monotonic response in cell activity a as function of dose..." [22]. In recent investigation it was shown that the zebra fish exposure to gamma radiation induced a non-monotonic dose-response in egg hatching. Fish were exposed to dose rates of $0.4,3.9,15$ and $38 \mathrm{mGy} / \mathrm{h}$, both during a 43.8-hour and 92-hour exposure. The total hatching rate was above $95 \%$ in all exposure groups, however, with significantly lower total hatching rate in fish exposed to $15 \mathrm{mGy} / \mathrm{h}$ compared to controls [19]. The absence of pronounced dose-related effects of the cytogenetic damage induced by gamma-radiation on dose, especially for some cell lines, was described in [23]. The results of this work suggest that individuals may differ with respect to their radiosensitivities. Authors of work [19] not mention the hormesis effect, but in modern investigations in radiobiology, dealing with the low dose effects of ionizing radiation and revealing non-monotonic dose-response effects, explain similar effects by the effect of hormesis [24]. We suppose that revealed in our investigation non-monotonic dose-response relation also may be connected to hormesis effect. Low doses of neutron radiation induce stress reactions in cells which protect cells from higher doses. The activation of protective mechanisms in course of continuous exposure to low doses of radiation may evoke the effect of "self-healing" of cells if the irradiation continues. Such an effect of self-healing results in decrease of HGQ reaction after cell exposure to doses of $54.8-71.3 \mathrm{mSv}$ (Fig. 4). In favor of such mechanism testifies the ability of cells to recover 64 min after the cell exposure to $11.4 \mathrm{mSv}$ dose of neutron radiation (Fig. 2). The data shoving the radioadaptive effect induced by $5 \mathrm{mGy} \mathrm{X}$-ray irradiation prior to the 2 Gy doses confirm the scheme proposed above. Interestingly, that radioadaptive effect was induced if the radioadaptive dose was applied only $15 \mathrm{~min}$ before challenging dose [25]. In our experiment the dose $4.6 \mathrm{mSv}$ was applied $22 \mathrm{~min}$ before cell obtained the total dose $54.8 \mathrm{mSv}$ (Tab. 1), which not induced reaction of heterochromatinization (Fig. 4).

\section{CONCLUSIONS}

The low-level neutron irradiation $(4.6-45.7 \mathrm{mSv})$ induces chromatin condensation (heterochronatinization) in nuclei of exfoliated human buccal epithelium cells. The process of chromatin condensation with dose increase is non-monotonous. More pronounced doses of radiation (54.8-146 $\mathrm{mSv}$ ) not induced the heterochromatinization. In our opinion, the nonmonotonous reaction of chromatin condensation reaction may be connected with hormesis effect. 

Y.G. Shckorbatov

\title{
ACKNOWLEDGMENTS
}

This investigation was supported by the research grant of Ukrainian Ministry of Education and Science, Grant No 0115 U000487.

\section{CONFLICT OF INTEREST}

Authors declare no conflict of interests.

\author{
Authors' ORCID ID \\ K.A. Kuznetsov (Di) https://orcid.org/0000-0003-0498-2489 \\ G.M. Onishchenko (D) https://orcid.org/0000-0001-6945-8413 \\ A.F. Shchus (iD https://orcid.org/0000-0001-6063-197X \\ Yu.G. Shckorbatov (iD https://orcid.org/0000-0002-3315-0932
}

\section{REFERENCES}

1. Chadwick, K. H. Leenhouts, H. P. (1981). The Molecular Theory of Radiation Biology. Heidelberg: Springer-Verlag Berlin.

2. Seth, I., Schwartz, J. L., Stewart, R. D. (2014). Neutron Exposures in Human Cells: Bystander Effect and Relative Biological Effectiveness. PLoS One, 2014, 9(6), e98947.

3. Stewart, R. D, Streitmatter, S. W., Argento, D. C. (2015). Rapid MCNP simulation of DNA double strand break (DSB) relative biological effectiveness (RBE) for photons, neutrons, and light ions. Phys. Med. Biol., 60, 8249-8274.

4. Falusi, O. A., Daudu, O. A. Y., Teni, K. J. (2014). The effect of fast neutron radiation on meiosis in pollen mother cells of Capsicumannum var. abbreviatum. The International Journal of Plant Reproductive Biology, 6(1), 31-34.

5. Barendsen, G. W., Broerse, J. J. (1969). Experimental radiotherapy of a rat rhabdomyosarcoma with $15 \mathrm{MeV}$ neutrons and $300 \mathrm{kV}$ X-rays. European Journal of Cancer, 5, 373-391.

6. Ng, C. Y., Kong, E. Y., Konishi, T. (2015). Low-dose neutron dose response of zebra fish embryos obtained from the neutron exposure accelerator system for biological effect experiments (NASBEE) facility. Radiation Physics and Chemistry, 114, 12-17.

7. Saeed, A., Raouf, G. A., Nafee, S. S. (2015). Effects of Very Low Dose Fast Neutrons on Cell Membrane and Secondary Protein Structure in Rat Erythrocytes. PLoS One, 10(10), e0139854. https://doi.org/10.1371/journal.pone.0139854

8. Zhang, J., He, Y., Shen X. (2016). $\gamma$-H2AX responds to DNA damage induced by long-term exposure to combined low-dose-rate neutron and $\gamma$-ray radiation. Mutation Research, 795, 36-40.

9. Zhang, D. Q., Liu, Q. J., Zhang, Q. Z. (2015). Dose-effect of ionizing radiation-induced PIG3 gene expression alteration in human lymphoblastoid AHH-1 cells and human peripheral blood lymphocytes. International Journal of Radiation Biology, 91(1), 71-80.

10. Chang, G. M., Gao, Y. B., Wang, S. M. (2015). Protecting intestinal epithelial cell number 6 against fission neutron irradiation through NF- $\kappa \mathrm{B}$ signaling pathway. BioMed Research International, 124721. doi.10.1155/2015/124721.

11. Miyatake, S., Kawabata, S., Hiramatsu, R. (2016). Boron Neutron Capture Therapy for Malignant Brain Tumors. Neurol Med Chir (Tokyo), 56(7), 361-371. doi: 10.2176/nmc.ra.2015-0297.

12. Kuznetsov, K. A., Kyzym, P. S., Onishchenko, G. M., Berezhnoy, A. Y., Shckorbatov, Y. G. (2015). Chromatin changes under exposure to neutron radiation. Advances in Cell Biology and Biotechnology: Proceedings of the International Conference (p. 83). Lviv, Ukraine.

13. Shckorbatov, Y. (2012). The state of chromatin as an integrative indicator of cell stress. In Simpson N. M. (Ed), Stewart V.J. (Ed). New Developments in Chromatin Research, 123-144.

14. Dumont, J., Euwart, D., Mei, B., Estes, S., Kshirsagar, R. (2016). Human cell lines for biopharmaceutical manufacturing: history, status, and future perspectives. Critical reviews in biotechnology, 36(6), 1110-1122.

15. Arnette, C., Koetsier, J. L., Hoover, P., Getsios, S., Green, K. J. (2016). In vitro model of the epidermis: connecting protein function to 3D structure. In Methods in enzymology, Academic Press, 569, 287-308.

16. Demirovic, D., Rattan, S. I. (2011). Curcumin induces stress response and hormetically modulates wound healing ability of human skin fibroblasts undergoing ageing in vitro. Biogerontology, 12(5), 437-444.

17. Shckorbatov, Y. G., Shakhbazov, V. G., Bogoslavsky, A. M. (1995). On age-related changes of cell membrane permeability in human buccal epithelium cells. Mech. Ageing Develop., 83, 87-90.

18. Wakeford, R. (2010). The meaning of low dose and low dose-rate. J. Radiol. Prot. 30(1), 1-3. 
19. Hurem, S., Martırn, L.M., Brede, D., Skjerve, E., Nourizadeh-Lillabadi R., Lind O.C., ...Lyche J.L. (2017). Dose-dependent effects of gamma radiation on the early zebrafish development and gene expression. PLoS ONE, 12(6): e0179259. https://doi.org/10.1371/journal.pone.0179259

20. Suman, S., Kumar, S., Moon, B. H. (2015). Relative Biological Effectiveness of Energetic Heavy Ions for Intestinal Tumorigenesis Shows Male Preponderance and Radiation Type and Energy Dependence in APC1638N/+ Mice. Int. J. Radiation Oncol. Biol. Phys., 95(1), 131-138.

21. Virhov, A. I., Dudkin, V. E. Kovalev, E. E. (Ed) et al. (1978). Atlas dozovyh harakteristik vneshnego ionizirujushhego izluchenija: Spravochnik. Moscow : Atomizdat (in Russian).

22. Batani, D., Conti, A., Masini, A., Milani, M., Costato, M., Pozzi, A., Triglia, A. (1996). Biosystem response to soft-X-rays irradiation: non-monotonic effects in the relevant biological parameters of yeast cells. Il Nuovo Cimento D, 18(5), 657-662.

23. Joshi, G.S., Joiner, M.C., Tucker, J.D. (2014). Cytogenetic characterization of low-dose hyperradiosensitivity in Cobalt-60 irradiated human lymphoblastoid cells. Mutation Research, 770, 69-78.

24. Kudryasheva, N. S., Rozhko, T. V. (2015). Effect of low-dose ionizing radiation on luminous marine bacteria: radiation hormesis and toxicity. J. Environ Radioact. 142, 68-77. doi: 10.1016/j.jenvrad.2015.01.012.

25. Murley, J. S., Arbiser, J. L., Weichselbaum, R. R., Grdina, D. J. (2018). ROS Modifiers and NOX4 Affect the Expression of the Survivin-Associated Radio-Adaptive Response. Free Radical Biology and Medicine. https://doi.org/10.1016/j.freeradbiomed.2018.04.547 